\title{
Respons Pertumbuhan Dan Produksi Dua Varietas Selada (Lactuca Sativa L.) Terhadap Pemberian Berbagai Sumber Nitrogen
}

Growth And Production Response of Two Varieties of Lettuce (Lactuca sativa $\mathbf{L}$.) on Application of Various Sources of Nitrogen

\author{
Jepriwira K. Ginting, Jonis Ginting*, Nini Rahmawati \\ Program Studi Agroteknologi, Fakultas Pertanian, USU, Medan 20155 \\ *Corresponding author : jonisginting@yahoo.com
}

\begin{abstract}
The research aims to determine the growth and production response of two varieties of lettuce (Lactuca sativa $\mathbf{L}$.) to the provision of various sources of nitrogen. This research was conducted in Lambar village, Tigapanah sub-district, Karo regency, Sumatera Utara Province with altitude of \pm 1200 meters above sea level, which started on July to September 2017. This research used a factorial randomized block design with 2 factors namely varieties of lettuce (crop and lettuce) and sources of nitrogen (urea fertilizer, chicken manure and Liquid organic fertilizer of rabbit urine). The parameters observed were plant height, greenish leaves, crop circle, fresh weight of plant per sample and fresh weight of plant per plot. The results showed that both varieties were significantly different in the parameters of plant height, greenish leaves, the number of leaves, and the fresh weight of the plant per sample. Application of nitrogen source showed differences in plant height at 10 weeks after move planting and fresh weight of plant per sample.
\end{abstract}

Keywords : crop lettuce, lettuce leaves, source nitrogen

\begin{abstract}
ABSTRAK
Penelitian ini bertujuan untuk mengetahui respons pertumbuhan dan produksi dua varietas selada (Lactuca sativa L.) terhadap pemberian berbagai sumber nitrogen. Penelitian ini dilaksanakan di Desa Lambar Kecamatan Tigapanah Kabupaten Karo Provinsi Sumatera Utara dengan ketinggian tempat \pm 1200 meter di atas permukaan laut, yang dimulai pada bulan Juli 2017 sampai September 2017. Penelitian ini menggunakan rancangan acak kelompok faktorial 2 faktor yaitu varietas selada (selada krop dan selada daun) dan sumber nitrogen (pupuk urea, pupuk kandang ayam dan POC urine kelinci). Parameter yang diamati adalah tinggi tanaman, kehijauan daun, lingkaran tanaman, bobot segar tanaman per sampel dan bobot segar tanaman per plot. Hasil penelitian menunjukkan bahwa kedua varietas berbeda nyata pada parameter tinggi tanaman, kehijauan daun, dan bobot segar tanaman per sampel. Pemberian sumber nitrogen menunjukkan perbedaan pada tinggi tanaman pada umur 10 MSPT dan bobot segar tanaman per sampel.
\end{abstract}

Kata Kunci : selada krop, selada daun, sumber nitrogen. 


\section{PENDAHULUAN}

Selada merupakan salah satu jenis tanaman sayur yang memiliki nilai ekonomi yang tinggi. Selada memiliki peran dalam program ketahanan pangan nasional. Ketahanan pangan (food security) tidak akan terwujud tanpa ketahanan nutrisi (nutritional security) dan hal tersebut berimbas pada kesehatan masyarakat yang akan semakin menurun. Konsep ketahanan nutrisi adalah menjamin ketersediaan pangan yang bernutrisi dan jumlahnya cukup bagi seluruh lapisan masyarakat. Nutrisi dan keamanan pangan tidak terpisahkan, ketika ketersediaan pangan berkurang, maka masyarakat akan mengkonsumsi makanan kurang bergizi dan tidak aman yang disebabkan karena bahaya kontamisasi kimia, mikroba, penyakit asal hewan dan sebagainya.

Kandungan gizi selada semakin disadari manfaatnya oleh masyarakat, sehingga ketersediaan sayuran khususnya selada menjadi hal penting dalam mendukung ketahanan pangan serta ketahanan nutrisi nasional. Oleh karena itu pemerintah menggalakkan program penananam sayuran maupun komoditas buah di sekitar pekarangan untuk mendukung program ketahanan pangan serta ketahanan nutrisi di lingkungan rumah tangga (Utami, 2003).

Minimnya ketersediaan unsur anorganik di dalam tanah menyebabkan rendahya produktivitas tanaman selada. Selain itu, untuk meningkatkan produksi tanaman selada daun dapat dilakukan dengan cara pemberian pupuk nitrogen. Pemberian nitrogen yang cukup pada tanaman di samping menjamin pertumbuhan yang baik juga meningkatkan hasil panen (Syarief, 1986; Cahyono, 2003).

Pupuk urea adalah salah satu jenis pupuk sumber nitrogen (45 - $46 \%)$, bersifat mudah larut dalam air, rnudah tercuci, mudah menarik air dari dalam udara (higroskopis), dan mempunyai pengaruh yang cepat terhadap pertumbuhan tanaman. Cara pemakaiamya adalah dengan dibenamkan di dalam tanah (Dwidjoseputro, 1981; Setyamidjaya, 1986).
Penggunaan pupuk organik mampu menjadi solusi dalam mengurangi pemakaian pupuk anorganik yang berlebihan. Namun kelemahan pupuk organik pada umumnya adalah kandungan unsur hara yang rendah dan lambat tersedia bagi tanaman. Pupuk organik dapat berbentuk padat maupun cair. Kelebihan pupuk organik cair adalah unsur hara yang dikandungnya lebih cepat tersedia dan mudah diserap akar tanaman (Pardosi, 2014).

Pupuk kandang ayam adalah pupuk organik yang berasal dari kotoran ayam yang bercampur antara kandungan nutrisi tinggi dan ramah lingkungan. sisa makanan serta alas kandang. Setiawan (2007), menyatakan bahwa kotoran ayam lebih cepat terdekomposisi. Hal ini disebabkan $(\mathrm{C} / \mathrm{N})$ kotoran ayam cukup rendah sehingga tidak diperlukan waktu yang lama untuk melakukan proses penguraian.

Pupuk organik cair urine kelinci bermanfaat untuk pertumbuhan tanaman, herbisida pra-tumbuh dan dapat mengendalikan hama penyakit, mengusir hama tikus, walang sangit dan serangga kecil pengganggu lainnya (Saefudin, 2009).

Adapun tujuan dari penelitian ini adalah untuk mengetahui respons pertumbuhan dan produksi dua varietas selada (Lactuca sativa L.) terhadap pemberian berbagai sumber nitrogen.

\section{BAHAN DAN METODE}

Penelitian ini dilaksanakan di lahan petani yang terdapat di Desa Lambar Kecamatan Tigapanah Kabupaten Karo Provinsi Sumatera Utara dengan ketinggian tempat $\pm 1.200 \mathrm{~m}$ di atas permukaan laut. Penelitian ini dilaksanakan pada bulan Juli 2017 sampai September 2017.

Bahan yang digunakan dalam penelitian ini adalah benih tanaman selada sebagai bahan tanam, top soil sebagai media tanam, polibag sebagai wadah persemaian, pupuk kandang ayam, urea, dan POC urine kelinci sebagai perlakuan.

Alat yang digunakan dalam penelitian ini adalah cangkul sebagai alat untuk membuat plot, meteran sebagai alat untuk 
mengukur, bambu untuk membuat kerangka naungan, timbangan untuk menimbang pupuk kandang ayam dan urea, SPAD 502 untuk menghitung nilai kehijauan daun, gembor sebagai alat untuk menyiram tanaman, ember sebagai wadah merendam bahan tanam.

Penelitian ini menggunakan Rancangan Acak Kelompok (RAK) Faktorial dengan dua faktor perlakuan dan 3 ulangan. Faktor I : varietas selada (V), terdiri atas 2 taraf $\mathrm{V}_{1}=$ Varietas selada krop, $\mathrm{V}_{2}=$ Varietas selada daun. Faktor II : pemberian sumber nitrogen $(\mathrm{N})$ terdiri atas 4 taraf : $\mathrm{N}_{0}=$ tanpa nitrogen, $\mathrm{N}_{1}=$ pupuk urea, $\mathrm{N}_{2}=$ pupuk kandang ayam, $\mathrm{N}_{3}=$ POC urine kelinci.

Terhadap sidik ragam nyata dilakukan analisis lanjutan dengan menggunakan Uji Beda Rataan Duncan Berjarak Ganda dengan taraf $5 \%$ (Bangun, 1991).

\section{HASIL DAN PEMBAHASAN}

\section{Tinggi Tanaman}

Berdasarkan hasil penelitian diperoleh bahwa tinggi tanaman selada varietas selada krop (V1) pada akhir pengamatan yaitu 15,53 $\mathrm{cm}$ sedangkan varietas selada daun (V2) sebesar 17,62 cm, tetapi pada deskripsi tanaman tinggi yang dapat dicapai oleh varietas selada krop adalah $25-30 \mathrm{~cm}$ dan varietas selada daun $27-32 \mathrm{~cm}$. Hal ini dapat terjadi dikarenakan ketersediaan unsur hara seperti Ca yang berfungsi untuk pembelahan sel, nitrogen untuk kebutuhan tanaman namun tidak terserap oleh tanaman karena $\mathrm{pH}$ tanah yang rendah yaitu 4,7. Hal ini sesuai dengan Foth (1998) yang menyatakan bahwa organisme pengikat nitrogen akan dihambat perkembangannya bila $\mathrm{pH}$ kurang dari 5,5.

Pada umur 10 MSPT interaksi antara varietas dan sumber nitrogen berpengaruh nyata terhadap tinggi tanaman. Dimana kombinasi perlakuan terbaik terdapat pada perlakuan V2N2 (varietas selada daun dengan pemberian pupuk kandang ayam). Hal ini dapat terjadi karena pada masa awal pertumbuhan belum terserapnya sumber nitrogen yang diberikan atau faktor lingkungan. Sedangkan pada fase pertumbuhan vegetatif $10 \mathrm{MSPT}$, sudah mulai timbul adanya perbedaan antar varietas tanaman dan sumber nitrogen yang diberikan. Hakim et al. (1986) menyatakan bahwa pupuk organik mempunyai efek sisa dimana haranya secara berangsur menjadi bebas dan tersedia

Tabel 1. Tinggi tanaman dua varietas selada terhadap pemberian berbagai sumber nitrogen.

\begin{tabular}{|c|c|c|c|c|c|c|}
\hline \multirow{3}{*}{$\begin{array}{c}\text { Umur } \\
\text { Pengamatan }\end{array}$} & \multirow{3}{*}{ Varietas } & \multicolumn{4}{|c|}{ Sumber Nitrogen } & \multirow[b]{2}{*}{ Rataan } \\
\hline & & $\begin{array}{c}\text { Tanpa N } \\
\text { (N0) }\end{array}$ & $\begin{array}{c}\text { Pupuk } \\
\text { Urea (N1) }\end{array}$ & $\begin{array}{c}\text { Pukan } \\
\text { Ayam (N2) }\end{array}$ & $\begin{array}{l}\text { POC urine } \\
\text { kelinci (N3) }\end{array}$ & \\
\hline & & \multicolumn{5}{|c|}{ 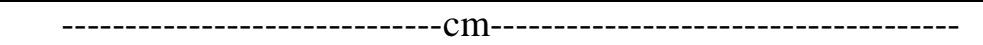 } \\
\hline \multirow{3}{*}{$6 \mathrm{MSPT}$} & Selada krop (V1) & 4,33 & 4,23 & 4,62 & 4,27 & 4,36 \\
\hline & Selada daun (V2) & 4,87 & 4,91 & 5,09 & 4,93 & 4,95 \\
\hline & Rataan & 4,60 & 4,57 & 4,85 & 4,60 & 4,65 \\
\hline \multirow{3}{*}{7 MSPT } & Selada krop (V1) & 6,64 & 6,78 & 6,70 & 6,80 & 6,73 \\
\hline & Selada daun (V2) & 7,71 & 7,80 & 7,86 & 7,79 & 7,79 \\
\hline & Rataan & 7,18 & 7,29 & 7,28 & 7,30 & 7,26 \\
\hline \multirow{3}{*}{8 MSPT } & Selada krop (V1) & 12,29 & 12,29 & 11,93 & 12,43 & $12,24 b$ \\
\hline & Selada daun (V2) & 14,38 & 14,62 & 14,78 & 14,59 & $14,59 \mathrm{a}$ \\
\hline & Rataan & 13,33 & 13,45 & 13,35 & 13,51 & 13,41 \\
\hline \multirow{3}{*}{9 MSPT } & Selada krop (V1) & 13,90 & 14,56 & 15,75 & 14,78 & $14,75 b$ \\
\hline & Selada daun (V2) & 16,06 & 16,57 & 17,77 & 16,61 & $16,75 \mathrm{a}$ \\
\hline & Rataan & 14,98 & 15,56 & 16,76 & 15,69 & 15,75 \\
\hline \multirow{3}{*}{$10 \mathrm{MSPT}$} & Selada krop (V1) & $14,87 \mathrm{~b}$ & $15,25 \mathrm{~b}$ & $16,09 \mathrm{a}$ & $15,10 \mathrm{~b}$ & 15,33 \\
\hline & Selada daun (V2) & $16,76 \mathrm{a}$ & $17,24 \mathrm{a}$ & $19,27 \mathrm{a}$ & $17,23 \mathrm{a}$ & 17,62 \\
\hline & Rataan & 15,81 & 16,25 & 17,68 & 16,16 & 16,48 \\
\hline
\end{tabular}

Keterangan : Angka yang diikuti oleh huruf yang berbeda adalah berbeda nyata berdasarkan Uji Jarak Berganda Duncan pada taraf $5 \%$ 
Tabel 2. Rataan kehijauan daun dua varietas selada terhadap pemberian berbagai sumber nitrogen.

\begin{tabular}{|c|c|c|c|c|c|}
\hline \multirow{3}{*}{ Varietas } & \multicolumn{4}{|c|}{ Sumber Nitrogen } & \multirow[b]{2}{*}{ Rataan } \\
\hline & $\begin{array}{c}\text { Tanpa N } \\
\text { (N0) }\end{array}$ & $\begin{array}{l}\text { Pupuk Urea } \\
\text { (N1) }\end{array}$ & $\begin{array}{c}\text { Pukan Ayam } \\
\text { (N2) }\end{array}$ & $\begin{array}{l}\text { POC urine } \\
\text { kelinci (N3) }\end{array}$ & \\
\hline & - & 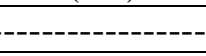 & -------Unit----- & 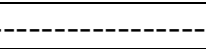 & 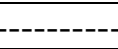 \\
\hline Selada krop (V1) & 10,80 & 10,47 & 8,97 & 9,26 & $9,87 \mathrm{a}$ \\
\hline Selada daun (V2) & 5,11 & 5,38 & 5,18 & 5,42 & $5,27 \mathrm{~b}$ \\
\hline Rataan & 7,95 & 7,92 & 7,07 & 7,34 & 7,57 \\
\hline
\end{tabular}

Keterangan : Angka yang diikuti oleh huruf yang berbeda adalah berbeda nyata berdasarkan Uji Jarak Berganda Duncan pada taraf $5 \%$ (huruf kecil).

bagi tanaman. Umumnya efek sisa pupuk organik akan memberikan cadangan unsur hara sehingga dapat dimanfaatkan untuk penanaman periode selanjutnya. Dan menurut Russel (1961) bahwa pemberian bahan organik akan membantu meningkatkan kemampuan tanah mengikat $\mathrm{N}, \mathrm{Ca}^{2+}, \mathrm{K}^{+}$, dan $\mathrm{Na}^{+}$yang kemudian dilepas secara berangsurangsur sehingga tersedia bagi tanaman. Dengan demikian pemberian pupuk organik dapat mendorong pertumbuhan tanaman yang lebih baik.

\section{Kehijauan Daun}

Berdasarkan hasil penelitian kehijauan daun menunjukkan bahwa kedua varietas menunjukkan pengaruh nyata terhadap kehijauan daun. Perbedaan kehijauan daun kedua varietas disebabkan perbedaan warna daun yang merupakan genetis tanaman itu sendiri. Hal ini sesuai dengan Keputusan Menteri Pertanian (2006) yang menyatakan deskripsi dari tanaman selada varietas selada krop yang memiliki warna daun hijau tua dan selada daun memiliki warna daun hijau kekuningan.

\section{Nilai Lingkaran Tanaman}

Hasil uji beda rataan pengaruh varietas selada dengan pemberian sumber nitrogen terhadap lingkaran tanaman disajikan pada Tabel 3.
Berdasarkan hasil penelitian menunjukkan bahwa kedua perlakuan yaitu varietas selada dan pemberian sumber nitrogen berpengaruh tidak nyata terhadap lingkaran tanaman. Hal ini dikarenakan lingkaran tanaman merupakan hasil pertumbuhan dari masing masing varietas pada saat masa vegetatifnya. Menurut Fahrudin (2009), lebar daun atau lingkaran tanaman merupakan hasil dari pertumbuhan vegetatif. Lebar daun dapat mendukung terlaksananya proses fotosintesis karena terdapat klorofil.

\section{Bobot Segar}

Hasil uji beda rataan pengaruh varietas selada dengan pemberian sumber nitrogen terhadap bobot segar tanaman disajikan pada Tabel 4 dan Tabel 5.

Berdasarkan hasil penelitian dapat dilihat bahwa selada krop (V1) dan selada daun (V2) memberikan pengaruh nyata terhadap bobot segar tanaman sampel. Hal ini tejadi karena tanaman sampel merupakan tanaman yang pertumbuhannya baik. Menurut Dwidjoseputro (1981) menyatakan bahwa suatu tanaman akan tumbuh baik dan subur apabila semua unsur hara yang dibutuhkan berada dalam jumlah yang cukup dan tersedia bagi tanaman. 
Tabel 3. Nilai lingkaran tanaman dua varietas selada terhadap pemberian berbagai sumber nitrogen.

\begin{tabular}{|c|c|c|c|c|c|}
\hline \multirow{3}{*}{ Varietas } & \multicolumn{4}{|c|}{ Sumber Nitrogen } & \multirow[b]{2}{*}{ Rataan } \\
\hline & $\begin{array}{c}\text { Tanpa N } \\
\text { (N0) }\end{array}$ & $\begin{array}{l}\text { Pupuk Urea } \\
\text { (N1) }\end{array}$ & $\begin{array}{l}\text { Pukan Ayam } \\
\text { (N2) }\end{array}$ & $\begin{array}{l}\text { POC urine } \\
\text { kelinci }(\mathrm{N} 3)\end{array}$ & \\
\hline & $-\cdots------$ & - & $-----c m-------$ & --------------- & ---------- \\
\hline Selada krop (V1) & 22,96 & 21,86 & 23,05 & 23,52 & 22,85 \\
\hline Selada daun (V2) & 21,96 & 22,77 & 23,80 & 22,93 & 22,87 \\
\hline Rataan & 22,46 & 22,32 & 23,42 & 23,23 & 22,86 \\
\hline
\end{tabular}

Keterangan : Angka yang diikuti oleh huruf yang berbeda adalah berbeda nyata berdasarkan Uji Jarak Berganda Duncan pada taraf $5 \%$ (huruf kecil).

Tabel 4. Bobot segar (g) tanaman sampel dua varietas selada terhadap pemberian berbagai sumber nitrogen.

\begin{tabular}{cccccc}
\hline & \multicolumn{4}{c}{ Sumber Nitrogen } & \\
\cline { 2 - 5 } Varietas & $\begin{array}{c}\text { Tanpa N } \\
(\mathrm{N} 0)\end{array}$ & $\begin{array}{c}\text { Pupuk } \\
\text { Urea (N1) }\end{array}$ & $\begin{array}{c}\text { Pukan Ayam } \\
(\mathrm{N} 2)\end{array}$ & $\begin{array}{c}\text { POC urine } \\
\text { kelinci (N3) }\end{array}$ & \\
\cline { 2 - 5 } & ---------------------------- & g------------------------------ \\
\hline Selada krop (V1) & 211,67 & 228,33 & 274,17 & 230,83 & $236,25 \mathrm{a}$ \\
Selada daun (V2) & 66,67 & 73,33 & 93,33 & 75,00 & $77,08 \mathrm{~b}$ \\
\hline Rataan & $139,17 \mathrm{c}$ & $150,83 \mathrm{~b}$ & $183,75 \mathrm{a}$ & $152,92 \mathrm{~b}$ & 156,67 \\
\hline
\end{tabular}

Tabel 5. Bobot segar $(\mathrm{kg})$ tanaman per plot dua varietas selada terhadap pemberian berbagai sumber nitrogen.

\begin{tabular}{cccccc}
\hline \multirow{2}{*}{ Varietas } & \multicolumn{4}{c}{ Sumber Nitrogen } & \\
\cline { 2 - 5 } & $\begin{array}{c}\text { Tanpa N } \\
\text { (N0) }\end{array}$ & $\begin{array}{c}\text { Pupuk } \\
\text { Urea (N1) }\end{array}$ & $\begin{array}{c}\text { Pukan Ayam } \\
\text { (N2) }\end{array}$ & $\begin{array}{c}\text { POC urine } \\
\text { kelinci (N3) }\end{array}$ & \\
\cline { 2 - 5 } & - & & & & \\
& & & & & \\
Selada krop (V1) & 3,16 & 3,73 & 4,03 & 3,48 & 3,60 \\
Selada daun (V2) & 1,53 & 1,66 & 1,85 & 1,71 & 1,69 \\
\hline Rataan & 2,35 & 2,70 & 2,94 & 2,59 & 2,64 \\
\hline
\end{tabular}

Tabel 5 menunjukkan bahwa kedua varietas memberikan pengaruh yang tidak berbeda nyata terhadap bobot segar per plot kedua varietas selada. Hal ini disebabkan karena sumber nitrogen yang tidak tersedia atau tidak terserap oleh tanaman secara keseluruhan. menurut Setyamidjaja (1986), menyatakan bahwa unsur hara merupakan unsur-unsur kimia tertentu yang dibutuhkan oleh tanaman untuk pertumbuhannya yang normal. Tidak tersedianya unsur hara bagi tanaman akan menyebabkan pertumbuhan terganggu dan tampaknya gejala-gejala kekurangan dan menurunnya produksi.

Berdasarkan hasil penelitian diperoleh data bahwa pemberian berbagai sumber nitrogen terhadap produksi dua varietas selada berpengaruh tidak nyata terhadap bobot segar tanaman per plot. Hal ini sesuai dengan
Nyakpa dkk. (1988) yang menyatakan bahwa kekurangan $\mathrm{N}$ akan membatasi produksi protein dan bahan penting lainnya dalam pembentukan sel baru pada tanaman.

Berdasarkan hasil penelitian bobot segar produksi tanaman secara keseluruhan belum mencapai hasil maksimal sesuai dengan deskripsi tanaman. Hal ini dapat terjadi karena unsur nitrogen yang diberikan kurang atau tidak terserap oleh tanaman. Hal ini sesuai dengan Sarief (1986) yang menyatakan bahwa nitrogen merupakan unsur hara utama bagi pertumbuhan tanaman, kekurangan nitrogen akan menyebabkan hambatan pertumbuhan tanaman yang berakibat pada rendahnya hasil tanaman. 


\section{SIMPULAN}

Varietas selada (Lactuca sativa L.) berpengaruh tidak nyata terhadap tinggi tanaman pada umur 6 MSPT dan 7 MSPT tetapi berpengaruh nyata pada umur 8,9 , dan 10 MSPT, kehijauan daun, serta bobot segar per sampel tetapi berpengaruh tidak nyata terhadap parameter lingkaran tanaman dan bobot segar per plot, Sedangkan pada sumber nitrogen berpengaruh tidak nyata terhadap tinggi tanaman pada umur $6,7,8$, dan 9 MSPT namun berpengaruh nyata pada umur 10 MSPT dan bobot segar per sampel, tetapi tidak berpengaruh nyata terhadap parameter lainnya yaitu kehijauan daun, lingkaran tanaman, dan bobot segar per plot, dan kombinasi perlakuan yaitu varietas selada dengan sumber nitrogen berpengaruh tidak nyata terhadap tinggi tanaman pada umur 6, 7, 8, dan 9 MSPT namun memberikan pengaruh nyata pada umur 10 MSPT dan berpengaruh tidak nyata terhadap parameter lainnya yaitu kehijauan daun, lingkaran tanaman, bobot segar per sampel, dan bobot segar per plot.

\section{DAFTAR PUSTAKA}

Bangun, M. K. 1991. Perancangan Percobaan. Fakultas Pertanian. USU-Press. Medan.

Cahyono, B. 2003. Teknik dan Strategi Budidaya Sawi Hijau (Pai Sai). Yayasan Pustaka Nusantara. 122 seatys 23 hal.

Dwijoseputro, D. 1981. Pengantar Fisiologi Tanaman. Jakarta : PT Gramedia. 282 hal.

Fahrudin, F. 2009. Budidaya Caisim (Brassica Juncea L.) Menggunakan Ekstrak Teh dan Pupuk Kascing. Skripsi. Univ. Sebelas Maret. Surakarta. 88 hal.

Foth. 1998. Dasar-Dasar Ilmu Tanah. Gadjah Mada University Press, Yogyakarta.

Hakim, N; M.Y. Nyakpa; A.M. Lubis; S.G. Nugroho; M.R. Saul; M.A. Diha; Go Ban Hong; dan H. Balley. 1986. Dasar-Dasar Ilmu Tanah. Universitas Lampung. Lampung. Hal : 137.
Nyakpa, M.Y., A.M. Lubis, M.A. Pulung, A.G. Amrah, A.Munawar, G.B. Hong dan N. Hakim. 1988. Kesuburan Tanah. Universitas Lampung, Lampung.

Pardosi, A. H., Irianto, dan Mukhsin. 2014. Respons Tanaman Sawi terhadap Pupuk Organik Cair Limbah Sayuran pada Lahan Kering Ultisol. Prosiding Seminar Nasional Lahan Suboptimal 2014, Palembang 26-27 September 2014. ISBN : 979-587-529-9.

Russel, J. E. 1961. Soil Condution and Plant Growth. 9th ed. Congmang. Furrold and Sons Ltd. Norwich.

Saefudin. 2009. Cara Pembuatan Pupuk Organik dari Urin Kelinci, BP3K Bansari Temanggung. Jawa Tengah.

Sarief, E. S. 1986. Ilmu Tanah Pertanian. Pustaka Buana, Bandung. Hal: 7-8.

Setiawan, L. 2007. Optimasi Konsentrasi Larutan Hara Pada Budidaya Selada (Lactuca Sativa L. Var Gand Rapids) Dengan Teknologi Hidroponik Sistem Terapung (THST). Skripsi. Progam Studi Hortikultura Fakultas Pertanian. IPB. Bogor.

Setyamidjaja, D. 1986. Pupuk dan Pemupukan. CV. Simplex. Jakarta. 122.

Utami, S. N. H. 2003. Nutrisi Tanaman. Jurusan Tanah Fakultas Pertanian Universitas Gadjah Mada. Yogyakarta. 